\title{
cAMP-induced Auditory Supporting Cell Proliferation is Mediated by ERK MAPK Signaling Pathway
}

\author{
Thomas J. Bell ${ }^{1}$ and John Carl Oberholtzer ${ }^{1,2}$ \\ ${ }^{1}$ Division of Neuropathology, Department of Pathology and Laboratory Medicine, University of Pennsylvania School of Medicine, \\ Philadelphia, PA 19104, USA \\ ${ }^{2}$ National Cancer Institute, Bethesda, MD 20892-8345, USA
}

Received: 5 November 2009; Accepted: 16 December 2009; Online publication: 27 January 2010

\begin{abstract}
Sensorineural hearing deficiencies result from the loss of auditory hair cells. This hearing loss is permanent in humans and mammals because hair cells are not spontaneously replaced. In other animals such as birds, this is not the case. Damage to the avian cochlea evokes proliferation of supporting cells and the generation of functionally competent replacement hair cells. Signal transduction pathways are clinically useful as potential therapeutic targets, so there is significant interest in identifying the key signal transduction pathways that regulate the formation of replacement hair cells. In a previous study from our lab, we showed that forskolin (FSK) treatment induces auditory supporting cell proliferation and formation of replacement hair cells in the absence of sound or aminoglycoside treatment. Here, we show that FSK-induced supporting cell proliferation is mediated by cell-specific accumulation of cyclic adenosine monophosphate (cAMP) in avian supporting cells and the extracellular signal-regulated kinase (ERK) mitogen-activated protein kinase (MAPK) pathway. By a combination of immunostaining and pharmacological analyses, we show that FSK treatment increases cAMP levels in avian auditory supporting cells and that several ERK MAP inhibitors effectively block FSK-induced supporting cell proliferation. Next, we demonstrate by Western blotting and immunostaining analyses the expression of several ERK MAPK signaling molecules in the avian auditory
\end{abstract}

Correspondence to: Thomas J. Bell - Department of Pharmacology . University of Pennsylvania School of Medicine, PA 19104, USA. Telephone: +1-215-8980420; fax: +1-215-5732236; email: tjbell@ upenn.edu epithelium and the cell-specific expression of B-Raf in avian auditory supporting cells. Collectively, these data suggest that FSK-induced supporting cell proliferation in the avian auditory epithelium is mediated by increases of cAMP levels in supporting cells and the cell-specific expression of the ERK MAPK family member B-Raf in supporting cells.

Keywords: auditory hair cells, supporting cells, cAMP, ERK

\section{INTRODUCTION}

Auditory hair cells are the sensory receptor cells of the cochlea. These cells transduce sounds into electrical signals for the central nervous system. The loss of auditory hair cells results in hearing deficiencies. Hair cell loss may result from normal aging or traumatic insults such as over-stimulation and exposure to ototoxic drugs. In humans and mammals, hearing loss is permanent because hair cells are not spontaneously replaced. Hearing aides are the most common treatment for such hearing disorders, but this solution does not address or improve the source of the problem, auditory hair cell loss. In other animals such as birds and fish, replacement hair cells are generated in response to hair cell loss and normal hearing or balance function is restored (BerminghamMcDonogh and Rubel 2003; Corwin and Oberholtzer 1997; Cotanche 1997). The avian is one of the beststudied model systems for hair cell regeneration. Hair cell regeneration in the avian cochlea was first documented in studies of hair cell loss following noise damage (Corwin and Cotanche 1988; Cotanche et al. 
1987; Cruz et al. 1987) and aminoglycoside treatment (Cruz et al. 1987). Auditory hair cells and supporting cells are located in the basilar papilla of the avian cochlea. Each avian basilar papilla contains $\sim 10,000$ hair cells and $\sim 30,000$ supporting cells (Tilney et al. 1986). Auditory hair cells differ progressively in size and shape along the tonotopic axis of the basilar papilla, and are interspersed amongst a population of homogenous supporting cells (Tilney et al. 1986). There is little proliferation, if any, in the undamaged avian auditory epithelium (Bermingham-McDonogh and Rubel 2003; Corwin and Oberholtzer 1997; Cotanche 1997). However, damage to the avian cochlea evokes proliferation of supporting cells and the subsequent differentiation of new, functionally competent replacement hair cells (McFadden and Saunders 1989; Tucci and Rubel 1990). These replacement hair cells acquire the appropriate morphological phenotypes for their positions in the 2-dimensional epithelium (Adler et al. 1993).

The signal transduction pathways that control the regeneration process in the avian auditory epithelium have yet to be clearly defined. In a previous study from our lab, we identified the cAMP/PKA pathway as the first signal transduction pathway in the formation of replacement hair cells in the avian auditory epithelium. We reported that treatment of undamaged cultured avian cochlear explants with several doses of the adenyl cyclase activator forskolin (FSK), or with cell-permeable cAMP analogs, induces DNA synthesis in auditory supporting cells and, after several days, results in the appearance of hair cells labeled with markers of DNA synthesis (Navaratnam et al. 1996). Although supporting cell proliferation in the auditory epithelium can be mediated by FSK treatment, the cellular responses to FSK treatment in the basilar papilla and the downstream targets of the cAMP/PKA pathway have yet to be elucidated. Here, we address both questions by first showing that FSK treatment of cultured cochlear explants increases cAMP levels in the auditory supporting cells, and then by identifying the extracellular signalregulated kinase (ERK) mitogen-activated protein kinase (MAPK) pathway as an important downstream signaling pathway in FSK-induced supporting cell proliferation.

\section{RESULTS}

Forskolin treatment induces CAMP accumulation in the avian basilar papilla

FSK treatment induces supporting cell proliferation and ultimately the formation of replacement hair cells in the avian basilar papilla (Navaratnam et al. 1996). Here, we determine the direct effects of FSK treatment in the basilar papilla by measuring the levels of cAMP after FSK treatments. Cochlear explants were cultured under conditions identical to those previously used to monitor FSK-induced supporting cell proliferationin standard medium with serum in the presence or absence of $100 \mu \mathrm{M}$ FSK. Explants were removed from culture at various time points and the basilar papillas dissected away. The levels of cAMP were measured by cAMP radioimmunoassay (RIA) and normalized to total DNA in each sample. FSK treatment rapidly increased cAMP levels approximately 56-fold above basal levels in the avian basilar papilla (Fig. 1). This initial rapid increase in cAMP accumulation is in agreement with previous investigations in other tissues and cell lines (Barovsky et al. 1983; Seamon and Daly 1986). The rise in cAMP accumulation peaked at approx. 30-60 min and declined slowly thereafter, returning to basal levels by $24 \mathrm{~h}$ (Fig. 1). Control cultures containing carrier DMSO at a final concentration $(1 \%)$ similar to that present in the experimental cultures, but without FSK, failed to increase cAMP levels (data not shown). The naturally occurring forskolin analog 1,9-dideoxy-forskolin $(100 \mathrm{~m} \mu \mathrm{M})$, which has previously been reported not to activate adenylyl cyclase (Laurenza et al. 1989) nor to stimulate DNA synthesis in the avian auditory epithelium (Navaratnam et al. 1996), also failed to increase cAMP levels (data not shown). We next measured the cAMP accumulations after FSK replenishments at 25 and $49 \mathrm{~h}$. The second FSK treatment increased cAMP levels approximately 11-fold above basal levels and the third FSK treatment increased cAMP levels approximately 5-fold above basal levels (Fig. 1). Our data verifies that treating cultured cochlear

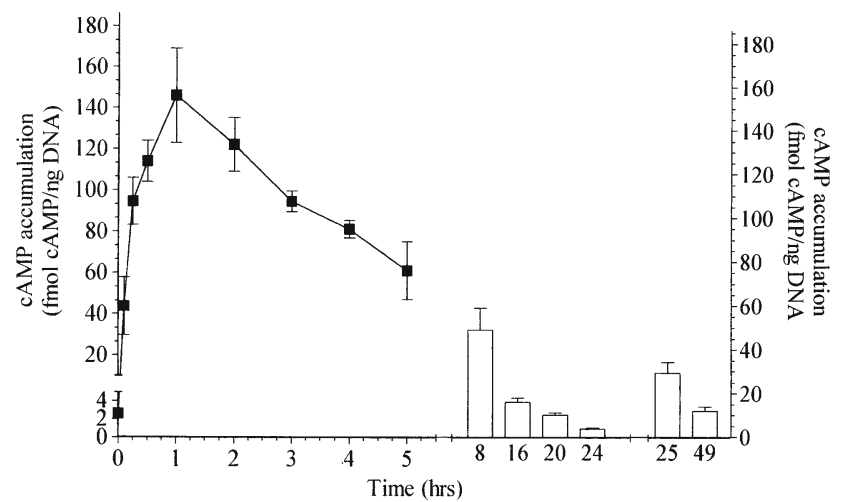

FIG. 1. FSK-treatment induces CAMP accumulation in the basilar papilla. Cochlear explants were cultured in standard medium with serum and $100 \mu \mathrm{M}$ FSK. Half the media volume and fresh FSK were replaced every $24 \mathrm{~h}$. Explants were removed from culture at the indicated time points and the basilar papillas dissected away. The levels of cAMP were measured by cAMP RIA normalized to total DNA in each sample. Untreated basal levels of cAMP at $0 \mathrm{~h}$ was $2.6 \pm$ $0.5 \mathrm{fmol} \mathrm{cAMP} / \mathrm{ng}$ DNA. After the initial FSK treatment at $0 \mathrm{~h}$ the cAMP accumulation increased to a maximum level of $146 \pm 33 \mathrm{fmol}$ cAMP/ng DNA at $1 \mathrm{~h}$ post-treatment. The second and third FSK treatments at 24 and $48 \mathrm{~h}$ also induced significant cAMP accumulation in the avian basilar papilla compared with untreated basal levels of cAMP. The cAMP accumulation was $29 \pm 4.0 \mathrm{fmol}$ cAMP/ng DNA $1 \mathrm{~h}$ post-treatment for the second FSK-treatment and $12 \pm 2.0 \mathrm{fmol}$ cAMP/ng DNA $1 \mathrm{~h}$ post-treatment for the third FSK-treatment. 
explants with FSK results in dramatic increases in cAMP levels in the avian basilar papilla. The initial FSK treatment produces the largest increase in cAMP levels compared with the second and third treatments, but all three significantly increase cAMP above basal levels in the avian basilar papilla.

\section{Forskolin induces CAMP accumulation in auditory supporting cells}

The avian basilar papilla contains $\sim 10,000$ auditory hair cells and $\sim 30,000$ supporting cells (Tilney et al. 1986), so next we sought to identify which cell types in the basilar papilla respond to FSK treatment by cAMP immunostaining. Cochlear explants were cultured under conditions identical to those used to measure cAMP levels in the presence or absence of FSK. Cochlear explants were then sectioned and stained with cAMP antibodies to detect the presence of cAMP-like immunoreactivity (cAMP-LI) in FSK-treated and untreated control cochlear explants (Shen et al. 1999; Wiemelt et al. 1997). FSK-treated cochlear explants showed a marked increase in cAMP-LI staining in the supporting cells, compared with the supporting cells in the untreated control explants (Fig. 2). Both auditory supporting cells and hair cells showed cAMP-LI staining in the FSK-treated cochlear explants, but the strongest cAMP-LI staining was detected in supporting cells
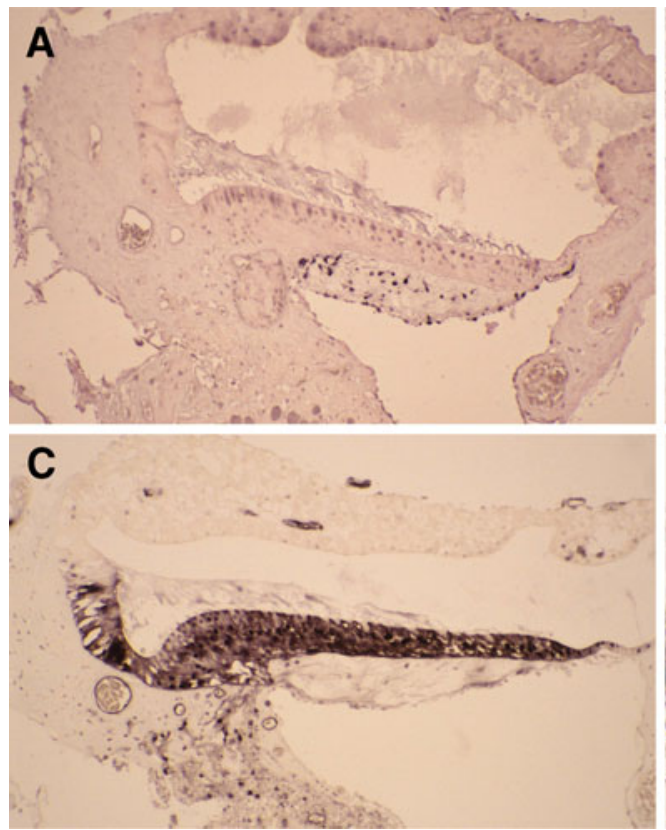

FIG. 2. FSK-induced cAMP accumulation occurs predominately in supporting cells. Cochlear explants were cultured in the presence or absence of FSK and processed for cAMP immunohistochemistry. The cochlear explants were sectioned and stained with cAMP antibodies to detect the presence of cAMP-like immunoreactivity (cAMP-LI). At both low and high magnification FSK-treated cochlear explants showed a marked increase in CAMP-LI staining, compared with explants cultured in the absence of FSK. A Low-magnification
(Fig. 2C and D). Collectively, these data show that FSK treatment increases cAMP levels in the basilar papilla, and that supporting cells show an obvious increase in cAMP levels. The cell-specific cAMP accumulation in auditory supporting cells following FSK treatment provides a key molecular link between the cAMP/PKA pathway and FSK-induced supporting cell proliferation.

\section{ERK MAPK inhibitors block FSK-induced supporting cell proliferation}

The downstream targets of the cAMP/PKA pathway during FSK-induced supporting cell proliferation remain to be identified. One likely target for this pathway is the ERK MAPK pathway. Here we show that inhibiting the ERK MAPK pathway blocks FSKinduced supporting cell proliferation. Cochlear explants were cultured for $72 \mathrm{~h}$ and stimulated three times with FSK in the presence or absence of the MAPK pathway inhibitors. FSK-induced supporting cell proliferation was monitored using BrdU immunohistochemistry. We used four different inhibitors (Radicicol, U-126, PD98059 and Apigenin) to block the ERK MAPK pathway at three different levels in the pathway: Raf (MAPKKK), MEK (MAPKK), and ERK (MAPK). Radicicol, which blocks all Raf isoforms from activating their downstream targets MEK-1 and 2 (MEK-1/2), was used to block the ERK MAPK pathway
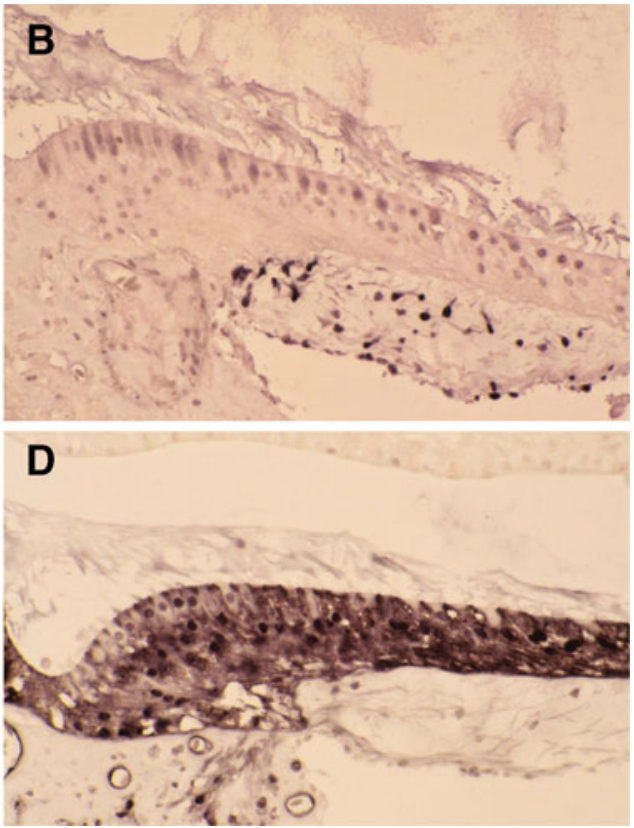

photomicrograph showing the CAMP-LI staining of an explant cultured in the absence of FSK. B High-magnification photomicrograph showing CAMP-LI staining of a cochlear explant cultured in the absence of FSK. C Low-magnification photomicrograph showing CAMP-LI staining of an explant cultured in the presence of $100 \mu \mathrm{M}$ FSK. D High-magnification photomicrograph showing CAMP-LI staining of a cochlear explant cultured in the presence of FSK. 
at the MAPKKK level (Soga et al. 1998). The presence of Radicicol blocked FSK-induced BrdU incorporation in a dose-dependent manner (Fig. 3A). The maximal block by Radicicol $(10 \mu \mathrm{M})$ was a $98 \%$ reduction in FSKinduced supporting cell proliferation. Next, the pharmacological inhibitors PD98059 and U-126, which blocks both MEK-1/2 proteins from activating their downstream targets ERK-1 and 2 (ERK-1/2), were used to block the ERK MAPK pathway at the level of MAPKK (Alessi et al. 1995; Favata et al. 1998). The both MAPKK inhibitors blocked FSK-induced BrdU incorporation in a dose-dependent manner (Fig. 3B and $\mathrm{C}$ ). The maximal block by U-126 $(10 \mu \mathrm{M})$ and PD98059 $(50 \mu \mathrm{M})$ was a $92 \%$ and $89 \%$, respectively. Lastly, the pharmacological inhibitor Apigenin, which blocks ERK1 and 2 proteins from activating downstream targets (Kuo and Yang 1995), was used to block the ERK pathway at the level of MAPK. FSK-induced BrdU incorporation was blocked in a dose dependent manner by the presence of Apigenin (Fig. 3D). The maximal block by Apigenin $(50 \mu \mathrm{M})$ was a $98 \%$ reduction in FSKinduced supporting cell proliferation.

By using four different ERK MAPK inhibitors, we show that that FSK-induced supporting cell proliferation in the avian basilar papilla can be pharmacologically blocked at all three levels of the ERK MAPK pathway. The ERK MAPK inhibitors blocked FSKinduced supporting cell proliferation at inhibitor concentrations that correspond well to the published $\mathrm{IC}_{50}$ concentrations. A previous study has reported that the ERK MAPK pathway is important for supporting cell proliferation in the avian utricular sensory epithelium. The ERK MAPK inhibitors U-126, PD98059, and Apigenin blocked avian utricular supporting cell proliferation in a dose dependent manner (Witte et al. 2001). Although there are differences between auditory and utricle supporting cells, our results are in agreement with this study. The effective block of FSK-induced supporting cells proliferation by four different MAPK inhibitors suggest that the ERK MAPK pathway must be unblocked during the formation of replacement hair cells following FSK application.

\section{Maximal FSK-induced supporting cell proliferation requires early activation of the MAPK pathway.}

To further characterize the role of the ERK MAPK pathway during FSK-induced BrdU-incorporation, we determined the time period during which inhibition of this pathway was most effective. To address this question, we cultured cochlear explants in the presence of MAPK inhibitors for three different time periods: $72 \mathrm{~h}$, the last $48 \mathrm{~h}$, or the last $24 \mathrm{~h}$. All three MAPK inhibitors produced similar results. The presence of Radicicol, U-126 or PD98059 for $72 \mathrm{~h}$ or the last $48 \mathrm{~h}$ of culture resulted in near-complete blocks of FSK-
A
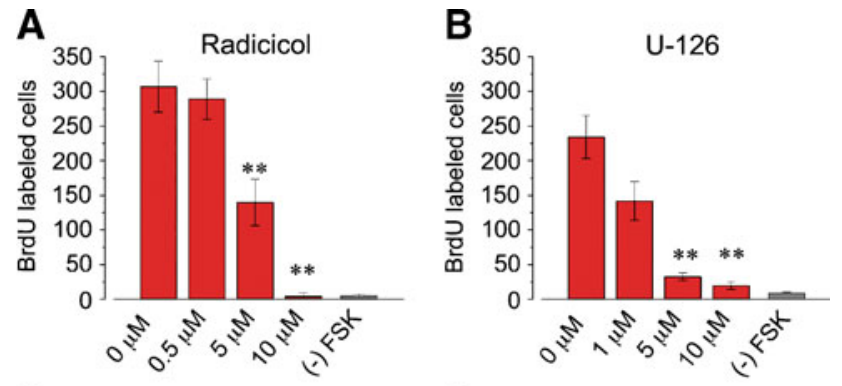

C

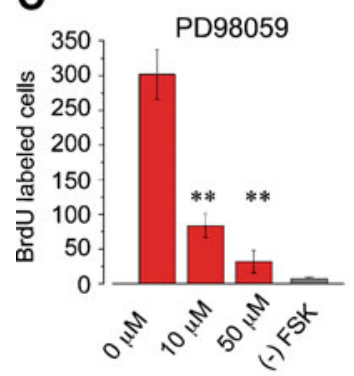

D

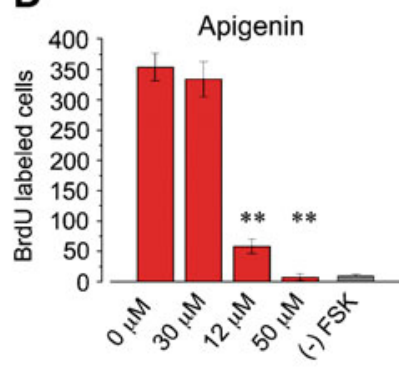

${ }^{\star} p<0.05$

$\star * \quad p<0.005$

FIG. 3. Multiple ERK MAPK inhibitors block FSK-induced BrdU incorporation. Cochlear explants were cultured for $72 \mathrm{~h}$ with $100 \mu \mathrm{M}$ FSK in standard medium in the presence or absence of the indicated ERK MAPK inhibitors at various concentrations. After $72 \mathrm{~h}$ in culture cochleas were fixed and processed for immunocytochemistry. The standard media contained $10 \%$ fetal calf serum and $0.01 \%$ BrdU. A Bar graph showing the average number of FSK-induced BrdU-labeled nuclei per cochlea in the presence of various concentrations of the Raf inhibitor Radicicol. The presence of 5 and10 $\mu \mathrm{M}$ Radicicol significantly inhibited FSK-induced BrdU incorporation compared with presence of $0.5 \mu \mathrm{M}$ Radicicol and $0 \mu \mathrm{M}$ Radicicol $\left(p<0.005\right.$; Radicicol $\left.\mathrm{IC}_{50}-1 \mu \mathrm{M}\right)$. The average number of BrdU labeled cells per cochlea was $307 \pm 36.9$ for $0 \mu \mathrm{M}$ Radicicol; $n=7$, $289 \pm 29.2$ for $0.5 \mu \mathrm{M}$ Radicicol, $n=9 ; 140 \pm 33.5$ for $5 \mu \mathrm{M}$ Radicicol, $n=7 ; 4.1 \pm 4.9$ for $10 \mu \mathrm{M}$ Radicicol, $n=8$; and $3.9 \pm 4.9$ for $(-)$ FSK, $n=5$. B Bar graph showing the average number of FSK-induced BrdU-labeled nuclei per cochlea in the presence of various concentrations of the MEK$1 / 2$ inhibitor $U-126$. The presence of 5 and10 $\mu \mathrm{M} U-126$ significantly inhibited FSK-induced BrdU incorporation compared with presence of $1 \mu \mathrm{M} U-126$ and $0 \mu \mathrm{M} U-126$ ( $\left.p<0.005 ; \mathrm{U}-126 \mathrm{IC}_{50}-1 \mu \mathrm{M}\right)$. The average number of BrdU labeled cells per cochlea was $234 \pm 30.7$ in the presence of $0 \mu \mathrm{MU}-126, n=4 ; 142 \pm 28.2$ in the presence of $1 \mu \mathrm{MU}-126$, $n=5 ; 32.4 \pm 5.3$ in the presence of $5 \mu \mathrm{M} \cup-126, n=5 ; 19.6 \pm 5.5$ in presence of $10 \mu \mathrm{M} \mathrm{U}-126, n=8$; and $5.8 \pm 1.9$ for (-) FSK, $n=4$. C Bar graph showing the average number of FSK-induced BrdU-labeled nuclei per cochlea in the presence of various concentrations of the MEK-1/2 inhibitor PD98059. The presence of 10 and $50 \mu$ M PD98059 significantly inhibited FSK-induced BrdU incorporation compared with the presence of $0 \mu \mathrm{M}$ PD98059 $\left(p<0.005\right.$; PD98059 IC $\left.\mathrm{I}_{50}-10 \mu \mathrm{M}\right)$. The average number of BrdU labeled cells per cochlea was $302 \pm 35.8$ in the presence of $0 \mu \mathrm{M}$ PD98059, $n=6 ; 83.8 \pm 17.4$ in the presence of $10 \mu \mathrm{M}$ PD98059 $n=6 ; 31.7 \pm 15.9$ in the presence of $50 \mu \mathrm{M}$ PD98059, $n=6$; and $5.5 \pm 2.9$ for (-) FSK, $n=5$. D Bar graph showing the average number of FSKinduced BrdU-labeled cells per cochlea in the presence of various concentrations of the ERK-1/2 inhibitor Apigenin. The presence of 30 and $50 \mu \mathrm{M}$ Apigenin significantly inhibited FSK-induced BrdU incorporation compared with the presence of $12 \mu \mathrm{M}$ Apigenin and $0 \mu \mathrm{M}$ Apigenin $\left(p<0.005\right.$; Apigenin $\left.\mathrm{IC}_{50}-25 \mu \mathrm{M}\right)$. The average number of BrdU labeled cells per cochlea was $354 \pm 22.9$ in the presence of $0 \mu \mathrm{M}$ Apigenin, $n=4$; $334 \pm 42.6$ in the presence of $12.5 \mu \mathrm{M}$ Apigenin, $n=4 ; 58.3 \pm 12.1$ in the presence of $30 \mu \mathrm{M}$ Apigenin, $n=4 ; 7 \pm 6$ in presence of $50 \mu \mathrm{M}$ Apigenin, $n=4 ; 10 \pm 5.4$ in presence of $75 \mu \mathrm{M}$ Apigenin, $n=4$; and $5.5 \pm 2.9$ for $(-)$ FSK, $n=4$. 
induced BrdU incorporation compared to FSK only controls (Fig. 4A, B, and C). However, when the presence of Radicicol, U-126 or PD98059 was limited to the last $24 \mathrm{~h}$ of culture, FSK-induced supporting cell proliferation was only reduced by $56 \%, 30 \%$, or $55 \%$, respectively (Fig. 4A, B, and C). These data show that the maximal FSK-induced supporting cell response requires activation of the ERK MAPK pathway during the first $48 \mathrm{~h}$ of culture. Previous studies in other systems have demonstrated that activation of the ERK MAPK pathway can lead to the activation of several different transcription factors or other serine-theonine kinases
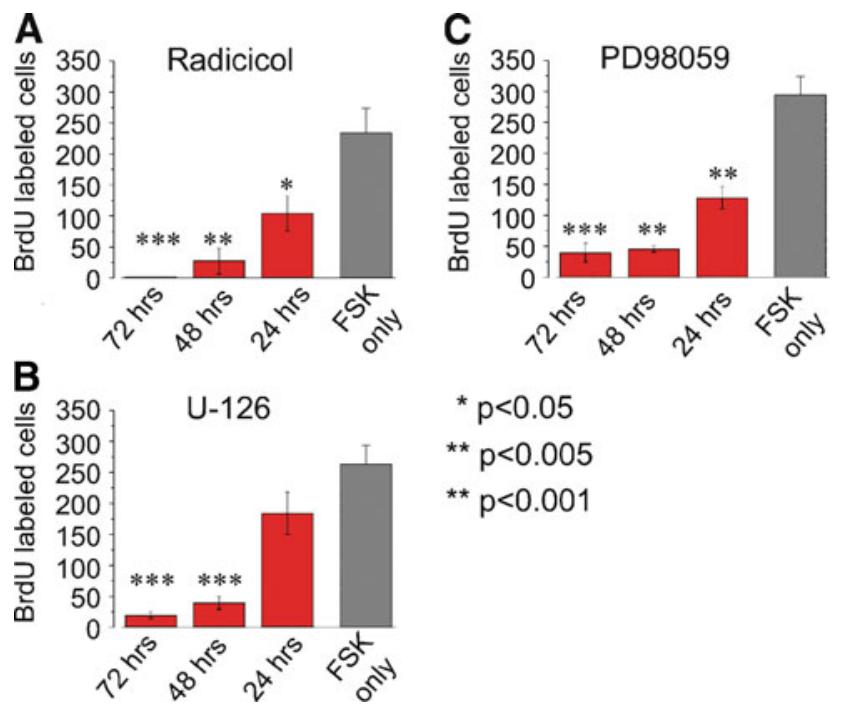

FIG. 4. Early activation of MAPK pathway is necessary for maximal response in FSK-induced BrdU incorporation. Cochlear explants were cultured for $72 \mathrm{~h}$ with $100 \mu \mathrm{M}$ FSK in standard medium in the presence or absence of ERK MAPK inhibitors for three different time periods: all $72 \mathrm{~h}$, last $48 \mathrm{~h}$, or last $24 \mathrm{~h}$. After $72 \mathrm{~h}$ in culture, cochleas were fixed and processed for immunocytochemistry, and the number of BrdU-labeled nuclei were counted. The standard media contained $10 \%$ fetal calf serum and $0.01 \%$ BrdU. A Bar graph showing the average number of FSK-induced BrdU-labeled nuclei per cochlea in the presence of $10 \mu \mathrm{M}$ Radicicol for three different time periods. All three conditions tested significantly inhibited FSK-induced BrdU incorporation compared with FSK only cochleas ( $p<0.001$ for all $72 \mathrm{~h}$ cochleas; $p<0.005$ for last $48 \mathrm{~h}$ cochleas; $p<0.05$ for last $24 \mathrm{~h}$ cochleas). The average number of BrdUlabeled cells per cochlea was $234 \pm 39.5$ for FSK only, $n=5 ; 1.8 \pm 0.7$ for all $72 \mathrm{~h}, n=6 ; 27 \pm 21$ for the last $48 \mathrm{~h}, n=5$; and $104.28 .5 \pm 4.9$ for the last $24 \mathrm{~h}, n=5$. B Bar graph showing the average number of FSK-induced BrdU-labeled nuclei per cochlea in the presence of $10 \mu \mathrm{M} \mathrm{U}-126$ for three different time periods. Two conditions, all $72 \mathrm{~h}$ and the last $48 \mathrm{~h}$, significantly inhibited FSK-induced BrdU incorporation compared with FSK only cochleas $(p<0.001)$. The average number of BrdU-labeled cells per cochlea was $263 \pm 30.5$ for FSK only, $n=5 ; 19.5 \pm 5.4$ for all $72 \mathrm{~h}, n=7 ; 39.6 \pm 10.6$ for the last $48 \mathrm{~h}, n=6$; and $184.2 \pm 34.3$ for the last $24 \mathrm{~h}, n=5$. C Bar graph showing the average number of FSK-induced BrdU-labeled nuclei per cochlea in the presence of $50 \mu \mathrm{M}$ PD98059 for three different time periods. All three conditions tested significantly inhibited FSK-induced BrdU incorporation compared with FSK only cochleas $(p<0.001$ for all $72 \mathrm{~h}$ cochleas and last $48 \mathrm{~h}$ cochleas; $p<0.005$ for last $24 \mathrm{~h}$ cochleas). The average number of BrdU-labeled cells per cochlea was $294 \pm 29.9$ for FSK only, $n=6 ; 39.5 \pm 15.9$ for all $72 \mathrm{~h}, n=6 ; 45.7 \pm 5$ for the last $48 \mathrm{~h}, n=5$; and $128.4 \pm 18$ for the last $24 \mathrm{~h}, n=5$. that regulate cellular proliferation and cell differentiation. (Widmann et al. 1999) Our results show that the maximal FSK-induced response requires the early activation of ERK MAPK pathway. This time course results suggest a transcriptional role for the ERK MAPK pathway in FSK-induced supporting cell proliferation rather than the activation of other serine-theonine kinases. The gene products induced by these transcription factors could be essential to produce the maximal FSK-induced supporting cell response.

\section{Multiple ERK MAPK proteins are present in the avian auditory epithelium}

Although FSK-induced supporting cell proliferation is pharmacologically blocked by ERK MAPK inhibitors, the presence of ERK MAPK proteins in the avian basilar papilla is currently unknown. Western blot analysis was used to show that two Raf isoforms are present in basilar papilla cell extracts, Raf-1 and B-Raf (Fig. 5A). This result is in agreement with previous studies in which it was reported that Raf-1 is ubiquitously expressed and B-Raf expression is restricted to neuronal tissues. The B-Raf antibodies detected two bands in the avian basilar papilla extracts (Fig. 5A). The dominant upper band corresponds to the $94 \mathrm{kD}$ $\mathrm{B}$-Raf isofom and the less intense lower band corresponds to the $68 \mathrm{kD}$ B-Raf isoform. Both Raf-1 and BRaf isoforms can be regulated by the cAMP pathway (Dumaz and Marais 2005). The third Raf isoform, ARaf, has been reported to be expressed predominately in renal tissue. As expected, we did not detect A-Raf in the basilar papilla (Fig. 5A). The Raf proteins regulate the MEK-1/2 proteins in the ERK MAPK pathway, so we next verified their presence in the basilar papilla by Western blot analysis. Antibodies specific to both MEK$1 / 2$ proteins detected a single band in the avian basilar papilla extracts (Fig. 5B), thereby confirming the presence of MEK- $1 / 2$ in the in the avian basilar papilla.

The MEK-1/2 proteins regulate the ERK-1/2 proteins in the ERK MAPK pathway, so we analyzed their expression patterns in the basilar papilla by Western blot analysis. First, we performed Western blot analysis with antibodies specific to both ERK-1 (44 kD) and ERK-2 (42 kD). As expected, we detected two bands that corresponded in size to ERK-1 and ERK-2 in the control extracts (Fig. 5C). In contrast, only one band that corresponded in size to ERK-2 was detected in the avian basilar papilla extracts (Fig. 5C). To further verify that this single ERK band was indeed ERK-2 and not ERK-1, we performed a second round of Western Blot analysis with ERK-2 specific antibodies (Fig. 5D). As expected, the ERK-2 specific antibodies detected two bands in both the control and chick basilar papilla extracts. These bands corresponded in size to unphosphorylated (lower band) and phos- 
A

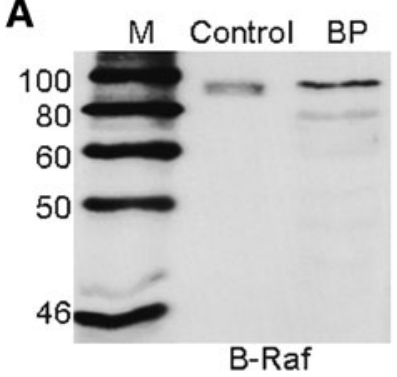

B

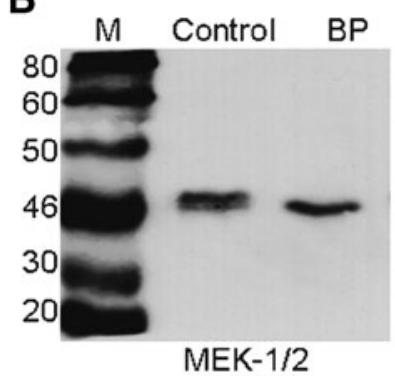

D

Control Control

$(+)$ serum (-) serum BP

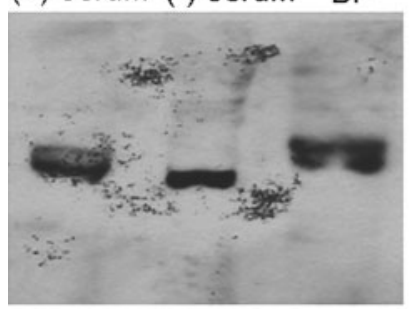

ERK-2

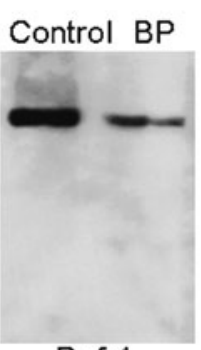

Raf-1

C

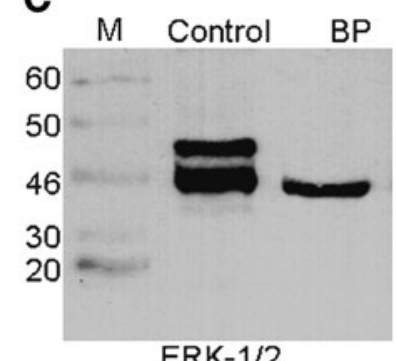

ERK-1/2

E

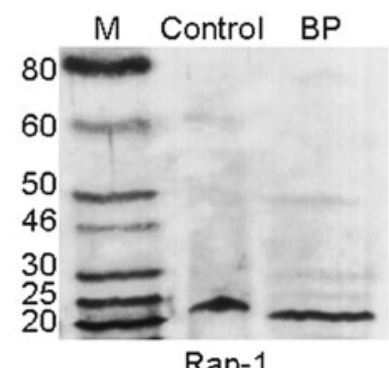

Rap-1

FIG. 5. Identification of ERK MAPK signaling molecules in avian basilar papilla. A Representative Western blots showing the expression patterns of Raf isoforms in basilar papilla extracts. Blots were probed with A-Raf (69 kD), B-Raf (94 or 68 kD), or Raf-1 (74 kD) specific antibodies. Both Raf-1 and B-Raf proteins were detected in the basilar papilla, but A-Raf was not. B Representative Western blot showing the expression of MEK-1/2 in basilar papilla extracts. Blots were probed with MEK-1/2 (45 kD) specific antibodies. C Representative Western blot showing the expression of ERK-1/2 in basilar papilla extracts. Blots were probed with ERK-1/2 (45 kD or $42 \mathrm{kD})$ specific antibodies. D Representative Western blot showing expression of ERK-2 in the basilar papilla. Blots were probed with ERK-2 (42 kD) specific antibodies. E Representative Western blot showing the expression of Rap-1 in basilar papilla extracts. Blots were probed with Rap-1 (21 kD) specific antibodies.

phorylated (higher band) ERK-2 proteins (Fig. 5D). Both sets of Western blots confirm the same result; the avian basilar papilla only expresses one MAPK, ERK-2.

The small Ras family GTPase called Rap- 1 has been shown to be an important intermediate between the cAMP/PKA and ERK MAPK pathways (York et al. 1998). Identifying the presence of this protein in the basilar papilla would provide a key connection between the cAMP/PKA and ERK pathways in the basilar papilla. By Western blotting with Rap-1 specific antibodies, we demonstrate that the Rap-1 protein is present in the avian basilar papilla extracts (Fig. 5E).

This is the first study to report that several key members of the ERK MAPK signaling pathway and Rap-1 are expressed in the avian auditory epithelium. Verifying the presence of B-Raf, Raf-1, MEK-1/2 and ERK-2 in the basilar papilla further strengthens the functional results with the ERK MAPK inhibitors (Fig. 3). Most importantly, the Raf isoforms are key integration points between the cAMP/PKA and ERK MAPK pathways. Identifying the presence of both Rap-1 and B-Raf in the basilar papilla supports a signaling model with cross-talk between the cAMP/PKA and ERK MAPK pathways.

\section{B-Raf expression is localized to supporting cells} in the avian auditory epithelium

The basilar papilla contains primarily two cell types, supporting cells and hair cells. B-Raf is a key molecule in cAMP/PKA regulation of the ERK MAPK pathway, so we determined the expression pattern of B-Raf in the avian auditory epithelium using indirect immunofluorescence on whole-mount cochleas. The tectorial membranes were removed from the cochleas by enzymatic digestion to allow antibodies direct access to the sensory epithelium, and also to prevent cross-reaction between the antibodies and the tectorial membrane. Single label experiments for B-Raf produced a punctate stain pattern that did not mirror the pattern of the tectorial membrane. The B-Raf staining pattern demonstrates the presence of B-Raf proteins in supporting cells (Fig. 6A and B). The nature of the structures responsible for the punctate pattern remains unknown. The structures appear to cluster around the borders of the hair cells. B-Raf is a cytoplasmic signaling protein and the expression of B-Raf can be restricted to distinct subcellular regions such as neuronal dendrites and cell bodies (Derkinderen et al. 1999; Morice et al. 1999). The punctate B-Raf structures may represent cytoplasmic B-Raf signaling complexes that clustered to discrete lumenal regions of supporting cells.

Control experiments were carried out with antibodies directed against the auditory hair cell specific protein myosin VIIA (Hasson et al. 1995). Our antimyosin-VllA results show that our methods did not damage the sensory epithelium (Fig. 6C and D). As negative controls, there was no detectable signal for BRaf with our methods in experiments staining the microdissected tectorial membrane alone or in cochleas with the primary B-Raf antibodies omitted (data not shown). This is the first study to report the expression of the ERK MAPK family member B-Raf in supporting cells of the avian auditory sensory epithelium. Previous studies in other systems have demonstrated that elevated levels of cAMP activate B-Raf (Dumaz and Marais 2005). During the formation of replacement hair cells following FSK application, the cell-specific expression of 

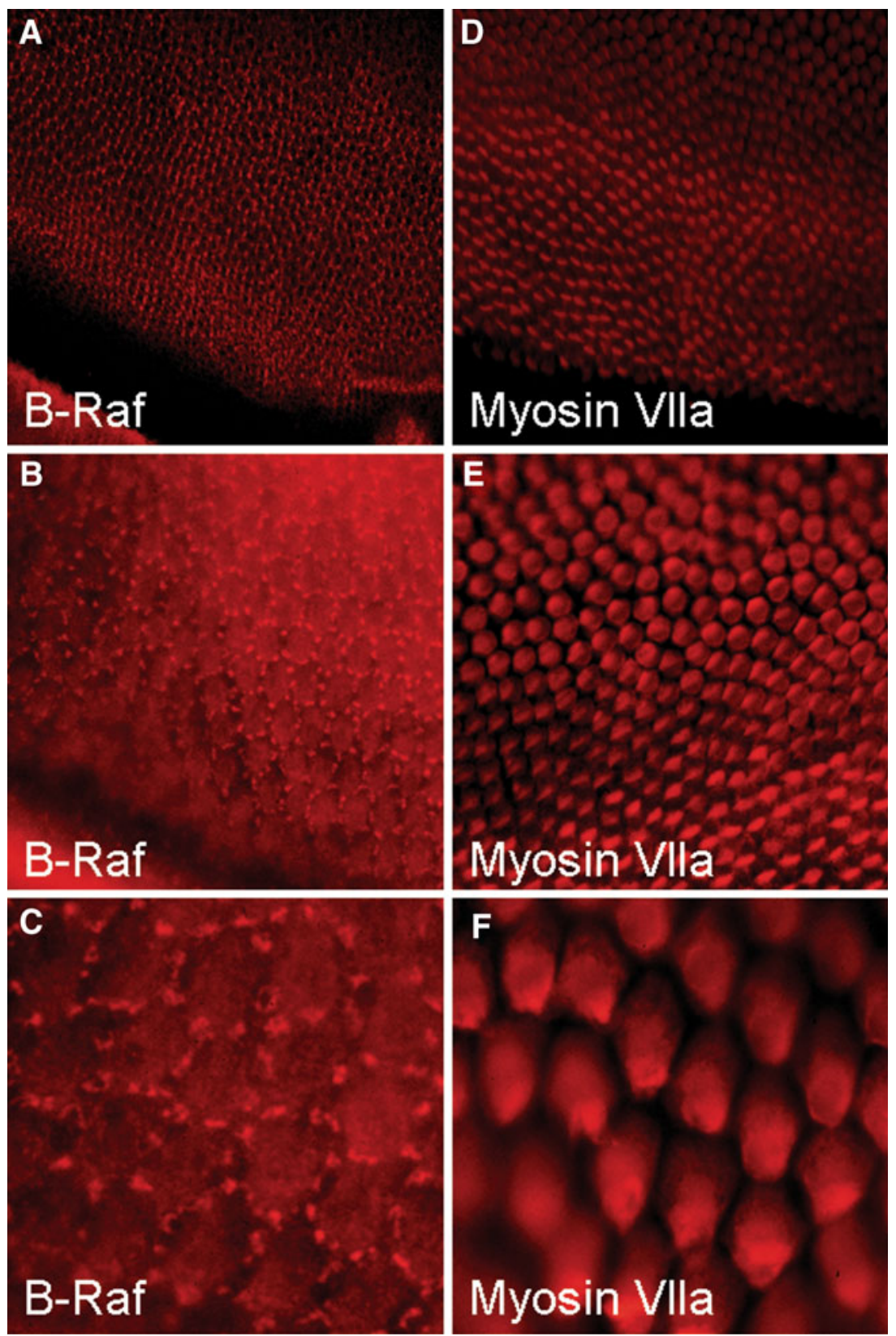

FIG. 6. Supporting cells express B-Raf in the avian basilar papilla. Cochleas were fixed and processed for whole-mount indirect immunofluorescence staining with B-Raf or Myosin Vlla antibodies. A, B, and C, Photomicrograph showing the B-Raf signal is restricted to auditory supporting cells as sharp interspersed clusters along the

B-Raf to supporting cells provides excitatory molecular link between the cAMP/PKA and ERK MAPK pathways in avian auditory supporting cells.

\section{Serum enhances FSK-induced BrdU incorporation} but is not required

To further determine the relationship between the cAMP pathway and the ERK MAPK pathway in this system, we analyzed the effects of serum on FSK-

entire length of auditory epithelium. D, E, and F, Photomicrographs showing immuostaining with antibodies directed against the hair cell-specific protein Myosin VIla. This staining highlights the location of hair cells and verifies that the auditory epithelium was undamaged during the staining procedure.

induced BrdU incorporation. Cochlear explants were cultured for $72 \mathrm{~h}$ and stimulated three times with FSK in the presence or absence of serum. DNA synthesis was monitored by BrdU immunohistochemistry. FSK treatment induced significant supporting cell proliferation in serum-free media; however, the absence of serum reduced FSK-induced supporting cell proliferation by approximately $40 \%$ (Fig. 7). This result is in agreement with several other studies that have demonstrated that the presence of serum or growth factors 


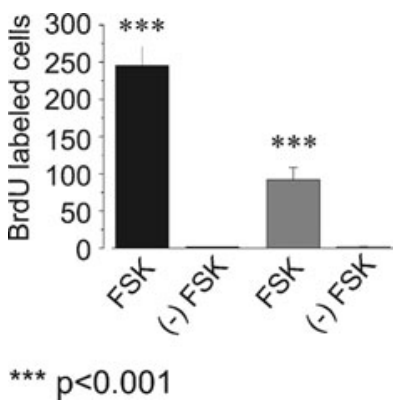

FIG. 7. Serum is required for maximal FSK-induced BrdU incorporation. Cochlear explants were cultured in the absence or presence of FSK in medium containing $10 \%$ serum or lacking serum. After $72 \mathrm{~h}$ in culture explants were fixed and processed for immunocytochemistry. Bar graph showing the average number of FSK-induced BrdU-labeled nuclei per cochlea from cultured cochlear explants in media with or without serum. The absence of serum significantly reduced the number of FSK-induced BrdU-labeled nuclei $(p<0.001)$. In serum-containing media (black bars), the average number of BrdU-labeled nuclei per cochlea was $245.8 \pm 25.5$ for FSK-treated, $n=6$, and $1.5 \pm 0.7$ for untreated (-) FSK, $n=6$. In serum-free media (grey bars) the average number of BrdU-labeled nuclei per cochlea was 92.3 \pm 16.1 for FSKtreated, $n=6$, and $1.8 \pm 0.6$ for untreated (-) FSK, $n=6$.

enhances supporting cell proliferation in the avian and mammalian utricles (Kuntz and Oesterle 1998; Lambert 1994; Montcouquiol and Corwin 2001b; Yamashita and Oesterle 1995; Zheng et al. 1997). Supporting cell proliferation in serum-free media has been previously shown in avian utriclular cultures (Warchol and Corwin 1996). Here, we show that FSK treatment can induce avian auditory supporting cell proliferation in serum free media. This result suggests that FSK-induced supporting cell proliferation requires the presence of serum factors to achieve the maximal response, but that exogenous mitogens in serum are not required for FSKinduced supporting cell proliferation. Some component(s) of serum are contributing to the enhancement of FSK-induced supporting cell proliferation independently of cAMP/PKA and ERK pathways.

\section{DISCUSSION}

Here we show that FSK-induced supporting cell proliferation is mediated by the cell-specific accumulation of cAMP in avian supporting cells and the ERK MAPK pathway. By measuring cAMP levels we verify that application of the adenyl cyclase activator FSK generates large and sustained increases in cAMP levels in the basilar papilla. By using cAMP immunohistochemistry we show that auditory supporting cells respond to FSK application by dramatically increasing cAMP levels, while hair cells appear to respond to such treatment to a much lesser degree. The ERK MAPK pathway regulates several important cellular functions including neuronal cell division (Dugan et al. 1999). The ERK MAPK pathway is a highly-conserved signaling module of three serine-threonine protein kinases, and all three levels of the ERK MAPK pathway (Raf, MEK $1 / 2$ or ERK-2) can be pharmacological targets to block FSKinduced supporting cell proliferation in the avian auditory epithelium. Western blot analysis was used to demonstrate the expression of the Ras family member Rap-1, and the ERK family members Raf-1, B-Raf, MEK$1 / 2$, and ERK-2 in the avian auditory epithelium. Lastly, we demonstrate the expression of B-Raf in avian auditory supporting cells by performing whole-mount immunochemistry on cochlear explants. The expression of B-Raf and cAMP accumulation in supporting cells following FSK treatment provide a molecular mechanism for the cAMP/PKA and ERK MAPK pathways to regulate FSKinduced supporting cell proliferation.

\section{FSK-induced supporting cell proliferation requires} Raf activation

Our results also show that FSK-induced supporting cell proliferation can be successfully blocked at all three levels of the ERK MAPK pathway. The initial signaling components in the ERK MAPK pathway are a group of proteins called MAPKKK. The Raf family contains three common MAPKKK proteins that activate the ERK pathway: A-Raf, B-Raf, and Raf-1 (Dumaz and Marais 2005; Hagemann and Rapp 1999; Widmann et al. 1999). We were able to block FSKinduced supporting cell proliferation at the level of MAPKKK with the Raf-selective inhibitor Radicicol. These data suggest an interaction between the mitogenic effects of FSK-treatment and the ERK MAPK pathway in the avian auditory epithelium. This interaction occurs upstream of MEK-1/2 at the level of Raf. The Raf inhibitor Radicicol is not isoformspecific for different Raf proteins, so we could not determine which isoform of Raf was regulating FSKinduced supporting cell proliferation. However, by Western blot analysis we did demonstrate the expression of B-Raf and Raf-1 (but not A-Raf) in the avian auditory epithelium. Both of these Raf isoforms interact with the cAMP/PKA pathway.

\section{Ras family members connect the cAMP/PKA and ERK MAPK pathways}

The cAMP pathway has been shown to be both a positive and a negative regulator of the ERK MAPK pathway (Dumaz and Marais 2005). Recent findings have identified some of the mechanisms that allow for cross-talk between the cAMP and ERK MAPK pathways by the Ras family members, Rap- 1 and Ras (Stork 2003). It has been reported that elevated levels of cAMP activate Ras and subsequently Ras inhibits the activation of Raf-1 (Dumaz and Marais 2005). In contrast, elevated levels of cAMP active Rap-1, and 
then Rap-1 activates B-Raf (Vossler et al. 1997). In this case the elevated levels of cAMP directly activate Rap-1 via the Rap-1 specific guanine-nucleotide exchange factor Epac (exhange protein activated by cAMP), which then activates B-Raf (de Rooij et al. 2000; de Rooij et al. 1998; Kawasaki et al. 1998). Rap-1 is a widely expressed protein that is activated by least three different second messengers, cAMP, calcium, and diacylglycerol. Rap-1 contributes to the regulation of several essential cellular functions such as cell proliferation and differentiation (Stork 2003). The presence of Rap-1 in the basilar papilla support a model that allows elevated levels of cAMP to activate the ERK MAPK pathway during FSKinduced supporting cell proliferation (see Fig. 8).

B-Raf is a key excitatory link between the cAMP/ PKA and ERK MAPK pathways

The ERK MAPK pathway includes the three Raf family members A-Raf, B-Raf, and Raf-1. B-Raf expression shows the most diverse expression patterns of the Raf family members in the nervous system. It can be cellspecific within a neuronal tissue (Dugan et al. 1999)

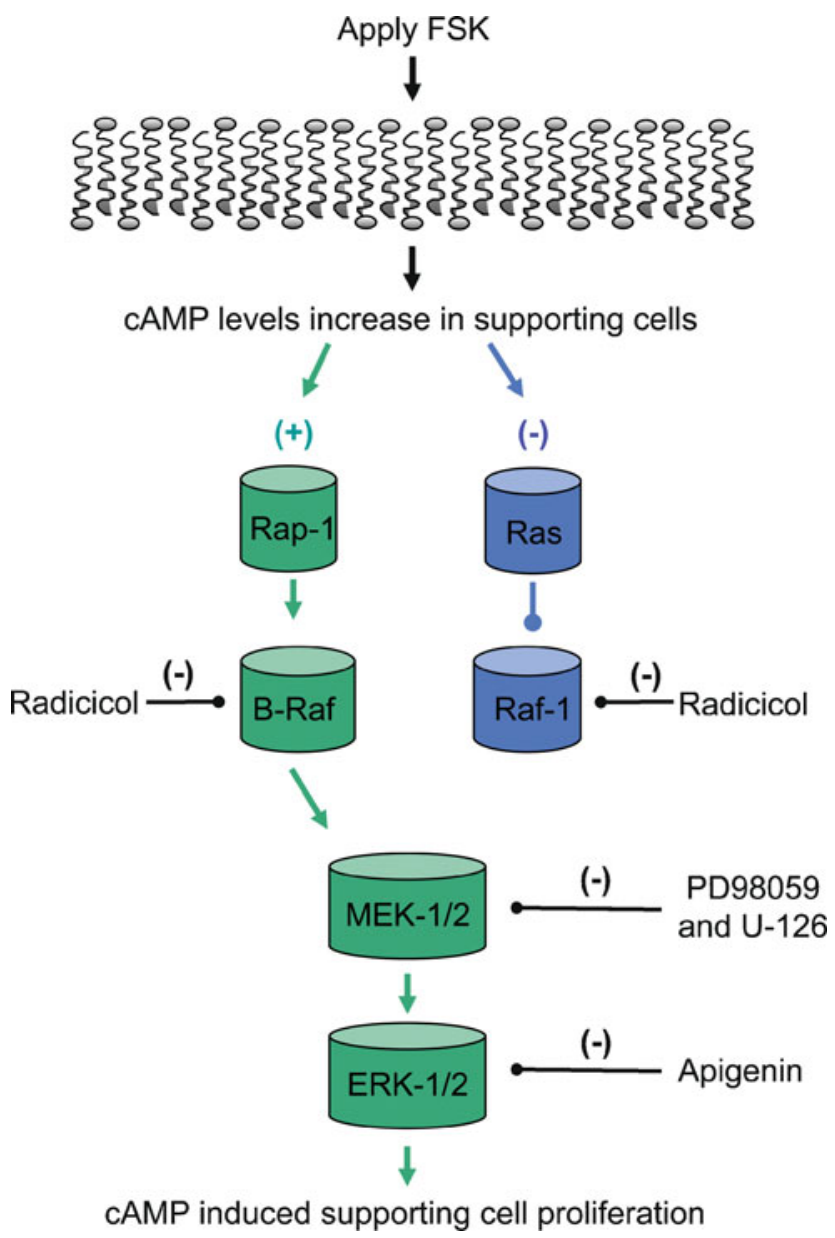

FIG. 8. A model for CAMP/PKA and ERK MAPK signaling during FSK-induced supporting cells proliferation. and subcellular-specific within an individual cell (Derkinderen et al. 1999; Morice et al. 1999). In agreement with these reports, B-Raf displays a distinct cell-specific and subcellular expression pattern in the avian auditory epithelium. The B-Raf staining pattern shows discrete punctate structures that appear to be predominately restricted to supporting cells and clustered around the borders of the hair cells. The nature of the punctate B-Raf structures is unknown, but they may represent B-Raf signaling complexes in discrete lumenal regions of supporting cells. This result has important implications for FSK-induced supporting cell proliferation, because the ERK MAPK pathway is regulated by the CAMP/PKA pathway at the level of Raf (MAPKKK). Depending upon which Raf isoforms are present in a cell, elevated levels of cAMP can either activate or inhibit the ERK MAPK pathway. The cAMP/PKA pathway inhibits Raf-1, thereby decreasing ERK-1/2 activity in cells that express only Raf-1. In contrast, the cAMP/PKA pathway activates BRaf, which ultimately increases the levels of ERK-1/2 activity in cells expressing B-Raf. The cell-specific expression of B-Raf in neuronal tissue provides a molecular mechanism by which the cAMP/PKA pathway can differentially regulate the ERK MAPK pathway in different cell types. The presence of B-Raf in a cell provides a dominant molecular switch that bypasses the negative signaling via Raf-1 and activates the ERK MAPK pathway. Elevated levels of cAMP and B-Raf expression have been reported increased the levels of cell proliferation in cultured neuronal cells (Dugan et al. 1999). In avian supporting cells, B-Raf could perform this same function to mitotically generate replacement hair cell.

\section{Future directions}

FSK treatment consistently stimulates the proliferation of only a small subset of supporting cells (on the order of $1 \%$ ), yet the pivotal cAMP-regulated signaling molecule B-Raf appears to be expressed uniformly across the entire length of the sensory epithelium. One explanation for this result is that a small subpopulation of "FSK-responsive" supporting cells exists in the avian basilar papilla. The upstream receptors and signaling proteins that regulate cAMP/PKA and B-Raf pathways could be restricted to a small subpopulation of "FSK-responsive" supporting cells. To date, only a few molecular markers, such as proliferation cell nuclear antigen (Bhave et al. 1995), Prox1 transcription factor (Stone et al. 2004), and fibroblast growth factor receptor 3 (Bermingham-McDonogh et al. 2001), have been identified to subsets of supporting cells. However, their functional significances are unknown. The identification of upstream receptors 
and signaling proteins that regulate cAMP/PKA and B-Raf pathways warrants further exploration.

There is a delicate balance between stimulatory and inhibitory signals during the formation of replacement hair cells. Alternatively, all supporting cells could be induced to dividing by FSK-treatment. Only a small subset (1\%) responds to FSK-treatment because local inhibitory signals from intact hair cells limit the number of proliferating supporting cells. After noise damage or aminoglycoside treatment, inhibitory signals play a key role in limiting the formation replacement hair cells to only occur in the damaged regions. In these models, the auditory sensory epithelium is restored with the appropriate number of hair cells (Brignull et al. 2009; Edge and Chen 2008; Stone and Cotanche 2007). This is not the case when important inhibitory pathways are disrupted. The disruption of $\mathrm{p} 27$ (Kip1) or RB signaling produces extra hair cells in the mouse auditory epithelium (Chen and Segil 1999; Sage et al. 2005). In future studies, it would be interesting to determine whether FSK-induced supporting cell proliferation can be enhanced by blocking local inhibitory signals. Identifying both the stimulatory and inhibitory signals that regulate the generation of replacement hair cells will provide valuable insight as to why mammalian supporting cells lack this important capacity.

Avian auditory supporting cells respond to FSK treatment by increasing cAMP levels, dividing and ultimately generating replacement hair cells. The accumulation of cAMP and expression of the B-Raf in supporting cells offers a powerful mechanism through which this can be accomplished. The cAMP/PKA pathway has also been reported to play a role in supporting cell proliferation in rat utricular sensory epithelium (Montcouquiol and Corwin 2001a). Analyzing the cellular responses to FSK treatment and the expression patterns of B-Raf in mammalian supporting cells merits future investigation. A better understanding of the differences between the avian and mammalian inner ears might suggest useful approaches to stimulating regeneration of the mammalian inner ear.

\section{MATERIALS AND METHODS}

\section{Cochlear Explant Cultures}

Cochleas were removed carefully under sterile conditions and maintained free-floating in DMEM (Gibco BRL, Rockville, MD) with $10 \%$ fetal calf serum for $72 \mathrm{~h}$ in $5 \% \mathrm{CO}_{2}$ at $37^{\circ} \mathrm{C}$. 5-bromo-2-deoxyuridine (BrdU; Sigma, St Louis, MO) was included at $0.01 \%$ to mark those cells undergoing DNA synthesis. Forskolin (Calbiochem, La Jolla CA), 1,9-dideoxyforskolin (Calbiochem, La Jolla CA), PD98059 (New
England Biolabs, Beverly, MA), U-126 (Research Biochemicals International, Natick, MA), and Radicicol (Research Biochemicals International, Natick, MA) were dissolved in dimethyl sulfoxide (DMSO; Sigma, St Louis, MO) and added to the culture medium at the indicated concentrations. Control cultures included carrier DMSO at a final concentration (1\%) identical to that present in experimental cultures. Each day half the media in both controls and experimental cultures were replaced.

\section{Detection of BrdU}

Cochleas were immobilized on a matrix (Sylguard 184, Dow Corning, Midland, MI) and the tegmentum vasculosum and tectorial membrane were dissected away. The cochleas were immersed in 10\% normal buffered formalin for at least $30 \mathrm{~min}$ followed by a 20-min incubation in $2 \mathrm{~N} \mathrm{HCl}, 0.1 \%$ Tween 20 . BrdU was detected immunohistochemically as previously described (Stone et al. 2004; Navaratnam et al. 1996). BrdU-labeled nuclei were counted by two independent observers and the numbers combined in the analysis. Statistical analyses were done using the unpaired Student's $t$ test. The data are presented as the mean $( \pm$ SEM) of BrdU-labeled nuclei per cochlea.

\section{Western Blot analysis}

Cochleas were cultured as described above. Cochleas were removed from culture at various time points and the basilar papillas dissected away. The harvested material was stored at $-80 \mathrm{C}$ until utilized. The protein content in each sample was determined by the Micro BCA (Pierce, Rockford, IL) Assay and equal amounts of protein were loaded in each lane of a given gel $(8-35 \mu \mathrm{g}$ per lane depending upon the antibody). Proteins were separated by SDS-polyacryalmide gel electrophoresis and blotted to nitrocellulose. Binding of primary antibody was detected using a horseradish-peroxidase chemiluminscent protocol according to the manufacturer supplied protocol.

\section{Whole-mount immunofluorence}

Cochleas were immobilized on a matrix (Sylguard 184, Midland, MI) and the tegmentum vasculosum was dissected away. Cochleas were immersed in $4 \%$ paraformaldehyde for at least $30 \mathrm{~min}$ followed by a $20-$ min incubation in phosphate-buffered saline (PBS) with $0.1 \%$ Tween 20 . The immunofluorescence staining protocol is previously described (Hasson et al. 1995; Hennig and Cotanche 1998).

\section{Antibodies}

The primary antibodies used were polyclonal ERK-2, A-Raf, and Raf-1 (Transduction Labs, Lexington, KY) 
at 1:1,000, polyclonal B-Raf (Santa Cruz, Santa Cruz, CA) at 1:1,000 or 1:50, and Rap-1 at 1:500 (Transduction Labs, Lexington, KY) and Myosin VIIA 1:200 (Gift from Dr. Hasson). The secondary antibodies used were antirabbit at 1:1,000 (New England Biolabs, Beverly, MA), anti-mouse at 1:8,000 (New England Biolabs, Beverly, MA), Alexa 488 at 1:400, Alexa 546 at 1:400 (Molecular Probes, Eugene, OR). Manufacturer-supplied positive control extracts served as the positive control for each antibody.

\section{Cyclic-AMP determination}

The cAMP content of the basilar papilla treated with forskolin was determined by cAMP RIA normalized to total DNA present. Following a specific time-interval of forskolin treatment, each cochlea explant was transferred to a sterile dish containing fresh media (Hanks' Balanced Salt Solution) and the phosphodiesterase inhibitor 3-isobutyl-1-methylxanthine (100 mM, IBMX) to minimize cAMP degradation during the dissection procedure. The basilar papilla was then quickly dissected away, transferred to a micro-centrifuge tube containing $200 \mathrm{ml}$ of $0.1 \mathrm{~N}$ HCL and quickly frozen. Samples were stored at $-20^{\circ} \mathrm{C}$ until processed. For determination of cAMP levels, the dissected basilar papilla samples were thawed, placed on ice, sonicated and the intracellular cAMP levels were measured by RIA (Amersham plc, UK).

\section{Determination of total basilar papilla DNA}

The total DNA content was measured according to the fluorometric procedure of Labarca and Paigen 1980. Stock of a high molecular weight calf thymus DNA solution $(50 \mathrm{mg} / 13.2 \mathrm{ml}$ ) from Boehringer Mannheim was diluted to an aliquot of $25 \mathrm{mg} / \mathrm{ml}$ with DNA Standard Dilution Buffer (100 mM NaCl, 10 mM EDTA, $25 \mathrm{mM}$ Tris, $\mathrm{pH}$ 7.0) and kept on ice. Aliquots of this were further diluted to a total volume of $1.0 \mathrm{ml}$ to prepare a standard curve in the range of $0-150 \mathrm{ng}$ DNA/ml. Hoechst 33,258 fluorescent dye (Pierce, Rockford, IL), known as bisbenzimide or (2'-[4-hydroxyphenyl]-5-[4-methyl-1-piperazinyl]-2,5'-bi-1H-benzimidazole, was dissolved in Assay Buffer $(0.1 \mathrm{M} \mathrm{NaCl}, 10 \mathrm{mM}$ EDTA, $10 \mathrm{mM}$ Tris, $\mathrm{pH}$ 7.0) at a working solution of $0.1 \mathrm{mg} / \mathrm{ml}$ and kept in a foil-wrapped glass container. Frozen specimens were thawed and $10 \mathrm{ml}$ of $2 \mathrm{~N} \mathrm{NaOH}$ was added to neutralize excess HCL. Hoechst 33258 working solution $(1.5 \mathrm{ml})$ was added to cuvettes containing $50 \mu \mathrm{l}$ of sample or DNA standard, mixed, and allowed to stand in the dark for 10-15 min. Fluorescence was measured in a Perkin-Elmer fluorometric spectrophotometer with excitation and emission wavelengths of 350 and $450 \mathrm{~nm}$, respectively.

\section{cAMP Immunohistochemistry tissue preparation}

For cAMP immunohistochemical investigations 5-10day-old chicks were decapitated and the temporal bones, including the intact cochlea, removed. All tissues and overlying cartilage were then removed to expose the underlying cochlea. This intact structure was then transferred to a well in a 24-well culture plate containing $1.0 \mathrm{ml}$ of DMEM with $10 \%$ fetal calf serum, with or without forskolin $(100 \mathrm{mM})$ in $5 \% \mathrm{CO}_{2}$ at $37^{\circ} \mathrm{C}$ for an appropriate time interval. Following treatment, the intact explants were fixed in a $5.5 \%(v / v)$ acrolein in $0.1 \mathrm{M}$ sodium acetate buffer, $\mathrm{pH} 4.75$ (acetate buffer) for $2 \mathrm{~h}$ at room temperature. Explants were then transferred to a glycine solution $(1.0 \mathrm{mg} / \mathrm{ml}$ in acetate buffer) for $1 \mathrm{~h}$ to quench the reaction and react with free acrolein, and then to $1 \%$ sodium cyanoborohydride $(w / v)$ (Sigma) for $1 \mathrm{~h}$ to reduce double-bonded oxygen and nitrogen and to complete cross-linking reactions (Peter et al. 1992). The explants were then transferred to a solution of $50 \mathrm{mM}$ TrisHCL, $0.4 \mathrm{M} \mathrm{NaCl}, \mathrm{pH} 4.75$ (TN solution) and the intact cochleas dissected from the surrounding cartilage. The harvested cochleas were returned to the TN solution while awaiting gel embedding. For gel embedding, the cochlea explants were infiltrated and embedded in melted pork gelatin (15\% pork gelatin, $0.02 \%$ sodium azide, $10 \%$ sucrose, PBS) for at least $1 \mathrm{~h}$ at $37^{\circ} \mathrm{C}$ (water bath) in a culture plate. Explants were aligned appropriately and the plate placed on ice until the gel solidified, and then stored at $4^{\circ} \mathrm{C}$ until used.

\section{cAMP Staining}

A single-label immunohistochemical procedure was used to visualize the presence of cAMP-LI in the avian cochlea. cAMP immunohisto-chemistry was performed with a polyclonal antiserum which has been shown to be highly specific for cAMP in tissues prepared as described above (Wiemelt et al. 1997). Cochlea explant sections, $6 \mu \mathrm{M}$, were cut in the coronal plane on a cryostat at $-17^{\circ} \mathrm{C}$, picked up on ProbeOn slides (Fisher) and air dried. Sections were then rehydrated with TN solution, blocked for $30 \mathrm{~min}$ with $50 \%$ bovine serum in PBS and incubated overnight in primary polyclonal rabbit cAMP antiserum (1:50 dilution) at $4^{\circ} \mathrm{C}$. Sections were then washed in TN solution for $5 \mathrm{~min}$ and incubated for $1 \mathrm{~h}$ in biotinylated goat anti-rabbit IgG (1:400 dilution). They were again washed for $5 \mathrm{~min}$ in $\mathrm{TN}$ solution and then incubated for $30 \mathrm{~min}$ in avidin-biotin horseradish peroxidase complex (ABC) at room temperature, according to manufacturer's instructions (Vectastain Elite, Vector Labs). Following a wash in TN solution, the antigen-antibody complexes were visualized by the addition of cold $3,3^{\prime}$ diaminobenzidine solution $(0.033 \%)$ in Tris buffer 
containing $\mathrm{H}_{2} \mathrm{O}_{2}(0.03 \%)$ and nickel sulphate $(0.01 \%)$. The reaction was terminated with excess deionised water. Sections were washed for 5 min in PBS, dehydrated in ascending concentrations of alcohol, cleared with xylene, and coverslipped with cytoseal. This procedure stained cAMP-LI black.

\section{REFERENCES}

Adler HJ, Poje CP, Saunders JC (1993) Recovery of auditory function and structure in the chick after two intense pure tone exposures. Hear Res 71:214-224

Alessi DR, Cuenda A, Cohen P, Dudley DT, Saltiel AR (1995) PD 098059 is a specific inhibitor of the activation of mitogenactivated protein kinase kinase in vitro and in vivo. $\mathrm{J}$ Biol Chem 270:27489-27494

Barovsky K, Pedone C, Brooker G (1983) Forskolin-stimulated cyclic AMP accumulation mediates protein synthesis-dependent refractoriness in C6-2B rat glioma cells. J Cyclic Nucleotide Protein Phosphor Res 9:181-189

Bermingham-McDonogh O, Rubel EW (2003) Hair cell regeneration: winging our way towards a sound future. Curr Opin Neurobiol 13:119-126

Bermingham-McDonogh O, Stone JS, Reh TA, Rubel EW (2001) FGFR3 expression during development and regeneration of the chick inner ear sensory epithelia. Dev Biol 238:247-259

Bhave SA, Stone JS, Rubel EW, Coltrera MD (1995) Cell cycle progression in gentamicin-damaged avian cochleas. J Neurosci 15:4618-4628

Brignull HR, Raible DW, Stone JS (2009) Feathers and fins: nonmammalian models for hair cell regeneration. Brain Res 1277:1223

Chen P, Segil N (1999) p27(Kip1) links cell proliferation to morphogenesis in the developing organ of Corti. Development 126:1581-1590

Corwin JT, Cotanche DA (1988) Regeneration of sensory hair cells after acoustic trauma. Science 240:1772-1774

Corwin JT, Oberholtzer JC (1997) Fish n' chicks: model recipes for hair-cell regeneration? Neuron 19:951-954

Cotanche DA (1997) Hair cell regeneration in the avian cochlea. Ann Otol Rhinol Laryngol Suppl 168:9-15

Cotanche DA, Saunders JC, Tilney LG (1987) Hair cell damage produced by acoustic trauma in the chick cochlea. Hear Res 25:267-286

Cruz RM, Lambert PR, Rubel EW (1987) Light microscopic evidence of hair cell regeneration after gentamicin toxicity in chick cochlea. Arch Otolaryngol Head Neck Surg 113:1058-1062

de Rooij J, Zwartkruis FJ, Verhejen MH, Cool RH, Nijman SM, Wittinghofer A, Bos JL (1998) Epac is a Rapl guaninenucleotide-exchange factor directly activated by cyclic AMP. Nature 396:474-477

de Rooij J, Rehmann H, van Triest M, Cool RH, Wittinghofer A, Bos JL (2000) Mechanism of regulation of the Epac family of cAMPdependent RapGEFs. J Biol Chem 275:20829-20836

Derkinderen P, Enslen H, Girault JA (1999) The ERK/MAP-kinases cascade in the nervous system. Neuroreport 10:R24-R34

Dugan LL, Kim JS, Zhang Y, Bart RD, Sun Y, Holtzman DM, Gutmann DH (1999) Differential effects of cAMP in neurons and astrocytes. Role of B-raf. J Biol Chem 274:25842-25848

Dumaz N, Marais R (2005) Integrating signals between cAMP and the RAS/RAF/MEK/ERK signalling pathways. Based on the anniversary prize of the Gesellschaft fur Biochemie und Molekularbiologie Lecture delivered on 5 July 2003 at the Special FEBS Meeting in Brussels. Febs J 272:3491-3504
Edge AS, Chen ZY (2008) Hair cell regeneration. Curr Opin Neurobiol 18:377-382

Favata MF, Horiuchi Ky, Manos EJ, Daulerio AJ, Stradley DA, Feeser WS, Van Dyk DE, Pitts WJ, Earl RA, Hobbs F et al (1998) Identification of a novel inhibitor of mitogen-activated protein kinase kinase. J Biol Chem 273:18623-18632

Hagemann C, Rapp UR (1999) Isotype-specific functions of Raf kinases. Exp Cell Res 253:34-46

Hasson T, Heintzelman MB, Santos-Sacchi J, Corey DP, Mooseker MS (1995) Expression in cochlea and retina of myosin VIIa, the gene product defective in Usher syndrome type 1B. Proc Natl Acad Sci USA 92:9815-9819

Hennig AK, Cotanche DA (1998) Regeneration of cochlear efferent nerve terminals after gentamycin damage. J Neurosci 18 (9):3282-3296

KaWasaki H, Springett GM, Mochizuki N, Toki S, Nakaya M, Matsuda M, Housman DE, Graybiel AM (1998) A family of cAMP-binding proteins that directly activate Rap1. Science 282:2275-2279

Kuntz AL, Oesterle EC (1998) Transforming growth factor-alpha with insulin induces proliferation in rat utricular extrasensory epithelia. Otolaryngol Head Neck Surg 118:816-824

KuO ML, YANG NC (1995) Reversion of v-H-ras-transformed NIH 3T3 cells by apigenin through inhibiting mitogen activated protein kinase and its downstream oncogenes. Biochem Biophys Res Commun 212:767-775

Labarca C, Paigen K (1980) A simple, rapid, and sensitive DNA assay procedure. Anal Biochem 102(2):344-352

LAMBERT PR (1994) Inner ear hair cell regeneration in a mammal: identification of a triggering factor. Laryngoscope 104:701-718

Laurenza A, Sutkowski EM, Seamon KB (1989) Forskolin: a specific stimulator of adenylyl cyclase or a diterpene with multiple sites of action? Trends Pharmacol Sci 10:442-447

McFadden EA, Saunders JC (1989) Recovery of auditory function following intense sound exposure in the neonatal chick. Hear Res 41:205-215

Montcouguiol M, CoRWIn JT (2001A) Brief treatments with forskolin enhance s-phase entry in balance epithelia from the ears of rats. J Neurosci 21:974-982

Montcouguiol M, Corwin JT (2001в) Intracellular signals that control cell proliferation in mammalian balance epithelia: key roles for phosphatidylinositol-3 kinase, mammalian target of rapamycin, and $\mathrm{S} 6$ kinases in preference to calcium, protein kinase $\mathrm{C}$, and mitogen-activated protein kinase. J Neurosci 21:570-580

Morice C, Nothias F, Konig S, Vernier P, Baccarini M, Vincent JD, BARNIER JV (1999) Raf-1 and B-Raf proteins have similar regional distributions but differential subcellular localization in adult rat brain. Eur J Neurosci 11:1995-2006

Navaratnam DS, Su HS, Scott SP, Oberholtzer JC (1996) Proliferation in the auditory receptor epithelium mediated by a cyclic AMP-dependent signaling pathway. Nat Med 2:1136-1139

Peter Me, Hall C, Rühlmann A, Sancho J, Terhorst C (1992) The Tcell receptor zeta chain contains a GTP/GDP binding site. EMBO J 11(3):933-941

Sage C, Huang M, Karimi K, Gutierrez G, Vollrath MA, Zhang DS, Garcia-Anoveros J, Hinds PW, Corwin JT, Corey DP, Chen ZY (2005) Proliferation of functional hair cells in vivo in the absence of the retinoblastoma protein. Science 307:1114-1118

Seamon KB, DaLy JW (1986) Forskolin: its biological and chemical properties. Adv Cyclic Nucleotide Protein Phosphorylation Res 20:1-150

Shen S, Wiemelt AP, McMorris FA, Barres BA (1999) Retinal ganglion cells lose trophic responsiveness after axotomy. Neuron 23:285-295

Soga S, Kozawa T, Narumi H, Akinaga S, Irie K, Matsumoto K, Sharma SV, Nakano H, Mizukami T, Hara M (1998) Radicicol leads to 
selective depletion of Raf kinase and disrupts K-Ras-activated aberrant signaling pathway. J Biol Chem 273:822-828

Stone JS, Cotanche DA (2007) Hair cell regeneration in the avian auditory epithelium. Int J Dev Biol 51:633-647

Stone JS, Shang JL, Tomarev S (2004) cProxl immunoreactivity distinguishes progenitor cells and predicts hair cell fate during avian hair cell regeneration. Dev Dyn 230:597-614

SToRk PJ (2003) Does Rap1 deserve a bad Rap? Trends Biochem Sci 28:267-275

Tilney LG, Tilney MS, Saunders JS, DeRosier DJ (1986) Actin filaments, stereocilia, and hair cells of the bird cochlea. III. The development and differentiation of hair cells and stereocilia. Dev Biol 116:100-118

Tucci DL, Rubel EW (1990) Physiologic status of regenerated hair cells in the avian inner ear following aminoglycoside ototoxicity. Otolaryngol Head Neck Surg 103:443-450

Vossler Mr, Yao H, York RD, Pan MG, Rim CS, Stork PJ (1997) cAMP activates MAP kinase and Elk-1 through a B-Raf- and Rap1-dependent pathway. Cell 89:73-82

WARCHOL ME, CORWIN JT (1996) Regenerative proliferation in organ cultures of the avian cochlea: identification of the initial progenitors and determination of the latency of the proliferative response. J Neurosci 16:5466-5477

Widmann C, Gibson S, Jarpe MB, Johnson GL (1999) Mitogenactivated protein kinase: conservation of a three-kinase module from yeast to human. Physiol Rev 79:143-180

Wiemelt AP, Engleka MJ, Skorupa AF, McMorris FA (1997) Immunochemical visualization and quantitation of cyclic AMP in single cells. J Biol Chem 272:31489-31495

Witte MC, Montcouquiol M, Corwin JT (2001) Regeneration in avian hair cell epithelia: identification of intracellular signals required for S-phase entry. Eur J Neurosci 14:829-838

Yamashita H, Oesterle EC (1995) Induction of cell proliferation in mammalian inner-ear sensory epithelia by transforming growth factor alpha and epidermal growth factor. Proc Natl Acad Sci USA 92:3152-3155

York RD, Yao H, Dillon T, Ellig CL, Eckert SP, McCleskey EW, STORK PJ (1998) Rap1 mediates sustained MAP kinase activation induced by nerve growth factor. Nature 392:622-626

Zheng JL, HeLbig C, GAO WQ (1997) Induction of cell proliferation by fibroblast and insulin-like growth factors in pure rat inner ear epithelial cell cultures. J Neurosci 17: 216-226 